\title{
An Experimental Research on the Integration of Ideal and Belief Education into English Major Courses in Chinese Universities
}

\author{
Yang Feng \\ $\mathrm{PhD}$, Assistant Professor, School of English Studies \\ Zhejiang International Studies University \\ E-mail: yang.feng@zisu.edu.cn
}

Received: May 12, 2020

Accepted: Sep. 18, 2020 Published: November 1, 2020

doi:10.5296/jse.v10i4.17664

URL: https://doi.org/10.5296/jse.v10i4.17664

Foundation Project: This paper is the research result of the project "An Empirical Study on the Integration of 'Young Students Learn Young Xi Jinping' into the Courses of English Majors in the Micro-era" (Project No. 2019QXQ1) which funded by Special Project of "Young Students Learn Young Xi Jinping" in Zhejiang International Studies University, China.

\begin{abstract}
The university phase is a critical period for the formation of students' outlook on life and career ideals, but some Chinese college students lack a correct understanding and motivation for learning, which needs to be improved. Through a teaching reform experiment to integrate ideal and belief education in the professional course in an academic year and 32 teaching weeks to 106 freshmen and 113 sophomores of English education majors. The result shows that compared with the control group who maintained the conventional teaching mode, the experimental group's performance in the outlook on life, academic development plans, professional ideals, and their motivation to learn well are all significantly improved, and the final exam scores have increased by $13-15 \%$ on average. The experiment shows that the use of appropriate materials and methods to integrate ideal and belief education in the teaching of professional courses in college can effectively promote students to form a correct outlook on life and career planning, improve learning enthusiasm and professional course performance, and help serve the society to achieve their ideals in life.
\end{abstract}

Keywords: Chinese universities, English majors, teaching reform, experimental research 


\section{Introduction}

Many surveys have found that many college students in current China have negative learning phenomena, and the proportion of male students is significantly higher than that of female students (Zhang \& Duan, 2010; Zhang, 2019; Guo \& Yan, 2019). The main reason is the lack of learning objective, motivation, interest, and methods (Zou et al., 2019; Yang \& Yang, 2020). Some students' class attendance is limited and the failure rate is high. More than half of the daily time is spent on using mobile phones to chat, watching videos and playing games. The use rate of mobile phones is extremely high but very little time is spent learning (Shi \& Sun, 2018). Many students have unclear learning goals, poor learning initiative, and seldom consider their social responsibilities (Wang, 2018).

The main reason for these situations is that after 30 years of reform and opening up, China's economy has made rapid progress, and people's living standards have been greatly improved, the supply of materials has become surplus, many families have stepped into the well-off and middle class, some college students have been spoiled since childhood, and lack of correct ideals, beliefs and career pursuit. A survey of 3,119 college students from 29 universities in China shows that the current situation of college students' ideals and beliefs is generally positive, but there are some worrying aspects, some college students lack or blur their ideals and beliefs, pay attention to personal ideal pursuit, have practicability and utilitarianism, have few opportunities to receive ideal and belief education, lack of second classroom construction of ideological and political education, poor teaching effect of ideological and political theory course, weak practical teaching foundation of ideological and political education, and insufficient campus culture construction (Lv et al., 2018).

The greater one's ideal is, the greater his contribution to the society and the more meaningful his life value is (Ruan, 2020). The growth of Xi Jinping, President of China, is actually the best example for college students to learn. During the 10-year turbulent period of China's "Cultural Revolution" in the 1960s and 1970s, schools across the country were closed, students could not go to school, there were no jobs and education, and national economy were stagnant and retrogressive, and urban students were sent to rural areas for farming. Xi, who was under 16 years old, also came to the Liang Jia village of poor rural areas in Northern Shaanxi Province. He experienced the poor and backward China's rural areas, and set up lofty ideals of loyalty and dedication to the country and rejuvenation of China. Therefore, he not only led the whole village to develop agricultural production and improve living standards, but also read extensively and accumulated knowledge. After seven years, he finally entered university for further study, and after graduation, he began to practice the dream of China's economic development from a county to a city, and finally led 1.4 billion Chinese people to realize the dream of national prosperity and the great rejuvenation of the Chinese nation (Liu, 2020). It can be said that if young $\mathrm{Xi}$ did not set up the lofty ideal of realizing the prosperity and strength of the country in the poor rural areas at that time, he would not have the motive to burn the midnight oil for 7 years, nor would he have the great feat of leading China to realize the great rejuvenation of the Chinese nation. 


\section{Mll Macrothink}

Journal of Studies in Education

ISSN 2162-6952

2020, Vol. 10, No. 4

Therefore, lofty ideals are very important for the development of individuals and society. College students' correct ideals and beliefs are not only related to their academic and professional development, but also related to the realization of Chinese dream of the great rejuvenation of the Chinese nation. But now many Chinese college students are "post 00s", and they embrace the Internet to grow up and live in the mobile era, they generally lack interest in the traditional report style ideological and political education, and the traditional mode of Ideological and political education is difficult to achieve good results (Zhang, 2019).

University is a critical period for the growth of life. What to learn and what to believe in this time is of great importance to one's life (Chen, 2017). The fundamental goal of ideological and political education in colleges and universities is to cultivate college students into qualified innovative talents who love the party and love the country, have good moral cultivation and professional skills by strengthening patriotism education, firm ideal and belief education, enhance mental health education, and strengthen professional ethics education. However, many students are not willing to listen to the traditional long report on ideological and political education. How to adjust and improve the ideological and political work mode in colleges and universities according to the characteristics of the "micro-era" becomes an issue. Xi Jinping, the China's leader, has pointed out: "It is necessary to use new media and new technology to make work alive, promote the integration of traditional advantages of ideological and political work with information technology, and enhance the sense of the times and appeal." (Wang, 2019).

Today's children are the hope of China's tomorrow, and if young people are strong, China will be strong; and to be strong, teachers trained by colleges and universities must be stronger in the future. Therefore, teacher's education in Chinese universities must improve the understanding of the ideals and beliefs of socialism among education major students, combine their own career plans with the rejuvenation of China, realize the sense of mission of the teaching profession, and whether they study hard during university is related to their graduation ability, their possibility to become a qualified people's teacher and to train a batch of qualified successors for national rejuvenation as a teacher in elementary and middle schools.

The author is a course teacher and class-head-teacher of the English Education Major of Zhejiang International Studies University, China and has more contact with students in and out of class. Therefore, the author has a better understanding of students' learning and thinking. The author also found that some students have the above situation. Although most students want to be a teacher in primary and secondary schools and study earnestly and work hard; but there are also a small number of students who lack ideals and beliefs, clear career plans, and positive learning attitudes. The author believes that only by truly helping students establish correct, lofty, and socially responsible socialist ideals and beliefs, and organically integrate the China's rejuvenation with their personal professional ideals, will they have a positive attitude towards life and study hard, will have a strong learning motivation and a sense of professional mission as a teacher, and will achieve better academic and work results. Therefore, this study proposed the teaching reform model of "integrating professional courses into ideal and belief education", that is, through the mobile teaching and WeChat group , 
integrating ideal and belief education content into professional curriculum teaching to allow students can integrate their career planning with the China's rejuvenation to establish the ideals and beliefs of studying and working hard for the rise of China, and improve learning motivation to obtain better academic performance in professional courses and obtain better academic and professional development. In order to verify the effectiveness of this teaching mode, this research conducted a one-year teaching experiment.

\section{Experimental Design}

\subsection{Research questions}

Does the teaching reform model of "professional courses integrate with ideal and belief education" promote the ideals and beliefs of Chinese college students and their professional course learning? How effective is it? How do students accept this teaching model? And what problems should be improved?

\subsection{Experiment objectives}

Through the integration of the learning and education content of "Young Students Learn Young Xi Jinping" in the teaching of English major courses, teaching experiments are carried out in the mode of "Micro-ideal and belief education in professional curriculum", and the experimental results are used to compare and analyze whether the teaching mode can enhance students' understanding of ideals and beliefs and professional courses? How effective is it? How do students accept this teaching mode? And what problem should be improved? Explore the teaching effect of the mode of belief and ideal course, and provide experience and reference for the belief and ideal education in colleges and universities.

\subsection{Experiment subjects}

One hundred and six students in 4 classes of the freshman year professional course "Comprehensive English", and 113 students in 4 classes of the sophomore year professional course "English Writing", totaling 8 classes with 219 students in Zhejiang International Studies University in China.

The English proficiency of the four classes in each grade is basically the same, and there is no significant difference in average scores. Two classes in each grade were randomly selected as the experimental group, and the other two classes as the control group. There are 108 students in the experimental group and 111 students in the control group.

The experimental group adopted the teaching mode of "Micro-Ideological Course in Professional Curriculum" in the corresponding professional course teaching, and integrated ideal and belief education into the professional course teaching; the control group kept the original conventional teaching mode.

\subsection{Experiment period}

October 2019-July 2020, 2 semesters, 16 weeks per semester, 32 weeks in total. 


\section{Methodology}

\subsection{Materials for teaching reform}

At present, many articles in the textbooks for English Majors in China's colleges and universities are extracted from the works of English-speaking authors. The contents lack the connection with China's national conditions and Chinese elements in the texts and teaching design, and the belief and ideal elements are nearly zero (Liu, 2017). Therefore, the teaching reform experiment plan to integrate the following ideal and belief education reading materials while continuing learning the following materials:

(1) Xi Jinping's Seven Years As An Educated Youth, an interview transcript compiled by the Party School Press of the Central Committee of the Communist Party of China, was first published in August 2017 with 310,000 words. This is an interview transcript compiled from the oral narrations of 29 interviewees, which include not only the educated youth in Beijing who once went to Shannxi Province with General Secretary Xi Jinping, but also the local villagers who got along with him day and night, as well as all aspects of knowing and interacting with him.

Through the interviewee's oral narration, the young Xi Jinping took root in the loess plateau of northern Shaanxi during the country's difficult time and reproduced the youthful face of Xi Jinping who has shared joys and sorrows with the people, brothers and sisters, blood and flesh, and a blend of fish and water. The interviewees vividly described the young Xi Jinping as the "youngest educated youth who went to the hardest place and the longest time to down to the countryside". He established his unswerving ideal pursuit and rooted in his patriotism for the people, practicing the will, persisting in learning, and constantly rising, this is the most vivid textbook for ideological and political education for college students, which can subtly cultivate the correct ideals, beliefs and career goals of college students, and establish a learning attitude of hard work and hard work immediately.

(2) Patriotism, Inspiring, Seeking Truth and Doing Good Deeds - Learning and Teaching Material for Young Student Learning Young Xi Jinping is a school-based teaching material for ideological and political education launched by Zhejiang International Studies University in March 2019. It recombines the relevant contents of Xi Jinping's seven years of educated youth, and writes cases in seven chapters, namely, conviction, diligence, hard work, for the people, friendship and politics. It guides students to learn and practice the excellent qualities of young Xi Jinping from the editor's comments, expanding reading and problem thinking.

(3) The English version of Xi Jinping: The Governance of China (Volume One), which was published by China Foreign Languages Publishing House on September 28, 2014. The book contains 79 talks, speeches, questions and answers, instructions, congratulatory letters, and so on in 18 topics of General Secretary Xi Jinping from November 15, 2012 to June 13, 2014. To help readers from various countries understand China's social system and historical culture, this book has made necessary notes. The book also includes 45 photos of General Secretary Xi Jinping from various periods to help readers understand his work and life. Since the 18th National Congress of the Communist Party of China, the Party Central Committee 
with Comrade Xi Jinping as the general secretary has led the entire party and people of all ethnic groups in the country on a new journey of reform, opening up and modernization. In the new practice of governing the country, General Secretary Xi Jinping published a series of important expositions, put forward many new ideas, new viewpoints and new theses, and profoundly answered the major theoretical and practical problems of the party and the country's development in the new era, and concentrated on showing the central leadership collective's ideas and strategies for governing the country.

Kuhn, an expert on China in the United States, believes that the book is of "milestone" significance, which expresses and enriches the "Chinese Dream". This book combines the dream and expectation of China's people of all nationalities to achieve national renewal and the path and steps to realize China's dream. The national governance it puts forward is not limited to the political sphere, but is a comprehensive ruling strategy including national life, people and society. "This book is written by President Xi Jinping's thought, which is both frank and comprehensive, reflecting the patriot's self-governance.

(4) Xi Jinping: The Governance of China (Volume Two) (English version), which was published and distributed by China Foreign Languages Press on November 7, 2017. It was collected by General Secretary Xi Jinping from August 18, 2014 to September 29, 2017. During the period, 99 speeches, talks, instructions, congratulatory messages, etc., were divided into 17 topics, which vividly recording the unity of the Party Central Committee with Comrade Xi Jinping at the core, leading the whole party and the people of all ethnic groups in the country to adhere to and develop socialism with Chinese characteristics in the new era, the great practice of and main content of $\mathrm{Xi}$ Jinping's socialist thoughts with Chinese characteristics in the new era, such as the "five in one overall layout" and the "four comprehensive strategic layout", poverty alleviation, anti-corruption, and the "One Belt and One Road" initiative. It fully embodies the Chinese wisdom and Chinese plan of the Communist Party of China to promote the building of a community with a shared future for mankind and the cause of peace and development of mankind.

The English version of The Governance of China has 515 pages in the first volume and 619 pages in the second volume, both in sextodecimo size. The text of the two books is over 1,000 pages and approximately 600,000 words. The translation team for the English version of the book has brought together dozens of elites in the translation industry, including several foreign experts, who proofread and revised more than ten times from translation to publication, third review, three proofreading. The Chinese translator first sorts out the English draft, and then foreign experts review the translation to ensure that the language is authentic, and finally it is reviewed and checked by 7 finalists. In order to do a good job in the translation of key words, foreign experts have a meeting every morning to discuss the translation of related words. For example, “五位一体” was considered by foreign experts for several days and finally decided to be "Five-point Strategy". Another example is “高举和平 对话旗帜", the literal translation is hold high the banner of peace and dialogue, to make the translation more authentic and easier to be understood by foreign readers, and it is finally translated as champion the cause of peace and dialogue. Therefore, the English version of the book was immediately read and praised by politicians and industry elites from all over the 
world as soon as it appeared on the market, and became the world's highest-circulation book among leaders of all countries (Wang, 2018).

(5) The English version of Up and Out of Poverty, which is a political theory work created by Xi Jinping. The Chinese version was first published in July 1992 with 110,000 words. The English version was translated and published by Foreign Languages Press in August 2017. The English version of the e-book was launched on April 9, 2018. The book contains important speeches and articles made by Comrade Xi Jinping during his work in Ningde, Fujian from September 1988 to May 1990. There are 29 articles in total, rich in connotation, very creative strategic thinking, highly forward-looking system theory and highly targeted practical viewpoints are narrated, with profound thinking, timeless chapters, insightful, vocal, thought-provoking and inspiring.

(6) Comparison of Chinese and Foreign COVID-19 Epidemic Prevention and Control, which is an electronic reading material collected by researcher since February 2020 for Chinese and foreign media to publicly report on the prevention and control of COVID-19 epidemics in various countries.

\subsection{Educational reform mode}

This experiment was carried out in the English education major courses "Comprehensive English" and "English Writing". The instructors are the two young teachers in the research group. It is planned to integrate the above-mentioned "Young Students Learn Young Xi Jinping" with the two courses, the specific integration model is as follows:

(1) Establishing a WeChat group for teaching and require students in experimental class to carefully read the book Xi Jinping's Seven Years As An Educated Youth outside of class. Teachers would extensively collect wonderful reviews and educational videos from various universities about the book. The micro-videos were uploaded to the teaching platform and class WeChat group based on 11 topics: power of model, eventful years, promising youth, hard work, firm conviction, patriotism, dedication to the beginning of the people, study hard, work hard, passionate emotion, mission of the times. Each student in the experimental class is required to write English summary and comment of the whole book or the key chapters, and at the same time talk about life ideals and beliefs in conjunction with their graduation and career planning as a teacher, and upload them to the course online teaching platform and class WeChat group, and teachers guide the whole classmates use English to conduct micro-chat and post micro-comments. These activities are included in the grades of the course.

(2)The research group spent 30 minutes a week in the course teaching to organize students in the experimental class to discuss the uploaded English summary in class, and use English to discuss their ideals and beliefs in combination with their own career plans, and guide the students to follow the example of the young Xi Jinping and establish the correct socialist ideals and beliefs, combining their own career planning with the great rejuvenation of the Chinese nation, and recognizing the sense of mission of the teaching profession. Through this way, student can become a qualified teacher of the people and cultivated qualified successors for a nation in the post of a teacher in primary and secondary schools. The class discussion is 
also included in the grades of the course.

(3) The Chinese to English translation practice of the "Comprehensive English" course used the wonderful paragraphs in the book Xi Jinping's Seven Years of Educated Youth for classroom teaching and homework.

(4) Students in the experimental class were organized to read the entire book Xi Jinping: The Governance of China (Volume One \& Two) (English version) and The English version of Up and Out of Poverty, and selected the wonderful chapters and paragraphs in the book to read and translate them into Chinese, and for oral practice, and applied writing to let students truly understand and realize the Chinese dream, as well as the Chinese wisdom of the Chinese Communist Party in promoting the construction of a community with a shared future for mankind, the cause of peace and development of mankind, and the Chinese plan to increase understanding and confidence in the superiority of the socialist system with Chinese characteristics.

(5)From February 2020, articles about on the prevention and control of the COVID-19 epidemic in various countries on Chinese and foreign media were uploaded to the WeChat group, and students were guided to discuss and compare the prevention and control of the COVID-19 epidemic between China and other countries in English, and compare the advantages of Chinese and foreign national systems and national cultures.

(6) The above-mentioned reading materials have around 1 million words in Chinese and English respectively. Considering the limited English proficiency of freshmen and sophomores, the research group selected articles of about 10,000 words from the above English materials, sent them to the WeChat group every week and encouraged students in the experimental classes to read and upload their own article translations or reading audio and video of the above learning materials to the teaching platform or class WeChat group to share with the whole class. This activity is also counted in marks of courses.

\subsection{Test methods and tools}

(1) Subject's scores of major course is judged by marks of the corresponding course final exam test;

(2) Students' learning attitude, ideals and beliefs, and career planning are tested through the "Questionnaire on Learning Attitudes, Ideals, Beliefs, and Career Planning of Education Majors" compiled by the research team. This questionnaire has referred to "The Attitude Survey Questionnaire" and "The Ideal and Belief Survey Questionnaire of College Students and Young Teachers" by Shen (2018), Liu Zhongyan (2018) and Liu Rong (2018). After trial and modification, the overall Cronbach Alpha coefficient is 0.81 .

At the same time, "The Outline of Interview on Learning Attitude, Ideal and Belief and Career Planning of Education Majors" was compiled and used to individual and group interviews. About $50 \%$ of the experimental subjects were chosen for individual and group interviews to deeply understand the above-mentioned related problems.

(3)The Interview Outlines of Comparing Chinese and Foreign Systems and Ethnic Culture 
from the Prevention and Control of the COVID-19 Epidemic was used to investigate the experimental subjects' knowledge and understanding on the comparison of Chinese and foreign systems and ethnic culture.

\section{Experimental results and analysis}

In the 32-week teaching reform experiment of 1 academic year ( 2 semesters), teachers of the research group sent more than 10,000 words and a total of 400,000 words of selected English articles to students in the experimental group in the course WeChat group every week. According to the survey statistics, students used mobile micro-reading mode to read materials carefully and discuss them on WeChat. In the first and second semesters, each student in the experimental group read 146 thousand English words on average in the $1^{\text {st }}$ semester and 215 thousand words on average in the $2^{\text {nd }}$ semester in extracurricular English reading. And each student posted 15.3 and 23.6 English posts with 137 and 186 words per post on WeChat in the $1^{\text {st }}$ and $2^{\text {nd }}$ semester respectively. On average, the total amount of English micro-reading and micro-writing of each student in the experimental group is 361 thousand and 65 thousand words respectively, which obviously promoted their English reading and writing ability. For detailed data, see Table 1-2.

Table 1. Comparison of students' test scores and extracurricular English reading and writing in the first semester

\begin{tabular}{|l|c|c|c|}
\hline \multicolumn{1}{|c|}{ Item } & $\begin{array}{c}\text { Experiment } \\
\text { Group } \\
\text { N=108 } \\
\text { students }\end{array}$ & $\begin{array}{c}\text { Control } \\
\text { Group } \\
\text { N=111 } \\
\text { students }\end{array}$ & $\begin{array}{c}\text { Sig. } \\
\text { P-value }\end{array}$ \\
\hline $\begin{array}{l}\text { Average English scores of National College } \\
\text { Entrance Examination(point out of 150 points })\end{array}$ & 115.95 & 116.5 & .153 \\
\hline Average score of Comprehensive English(point) & 84.3 & 78.7 & .000 \\
\hline Average score of English writing(point) & 81.5 & 76.3 & .000 \\
\hline $\begin{array}{l}\text { Average number of words in extracurricular } \\
\text { English reading(ten thousand words/student) }\end{array}$ & 14.6 & 0 & .000 \\
\hline $\begin{array}{l}\text { Average number of Wechat English short } \\
\text { articles and posts(number/student) }\end{array}$ & 15.3 & 0 & .000 \\
\hline $\begin{array}{l}\text { Average number of words per English } \\
\text { essay(word) }\end{array}$ & 137 & 0 & .000 \\
\hline
\end{tabular}

From the data in Table 1 and Table 2, the average English scores of the two groups of students in the college entrance examination are close to 120 points, and there is no significant difference; after entering the university, they all study in English education major, using the same course materials and final exam papers. After 16 weeks of study in the first semester, the average final exam scores of students in the experimental group in the Comprehensive English and English Writing courses were 84.3 and 81.5 on average, which were $7.12 \%$ and $6.82 \%$ higher than those of the control group respectively. By the end of the second semester, the average test scores of the two courses for the experimental group were 
91.2 and 87.4 , which were $15.01 \%$ and $12.77 \%$ higher than those of the control group.

It can be seen that the teaching reform mode carried out in the experimental group has pushed a large number of selected English micro-reading materials on ideal and belief education through the WeChat group of English majors. The fragmented micro-reading has expanded the English reading amount of students in the experimental group. Discussing micro-writing has also developed their English writing skills, and the test scores of related English courses have naturally improved.

Table 2. Comparison of the scores in the final exam of second semester and the situation of extracurricular English reading and writing

\begin{tabular}{|c|c|c|c|}
\hline Item & $\begin{array}{c}\text { Experimental } \\
\text { Group } \\
\mathrm{N}=108 \\
\text { students } \\
\end{array}$ & $\begin{array}{l}\text { Control } \\
\text { Group } \\
\mathrm{N}=111 \\
\text { students }\end{array}$ & $\begin{array}{l}\text { Sig } \\
\text { P-value }\end{array}$ \\
\hline $\begin{array}{l}\text { Average scores of } \quad \text { Comprehensive } \\
\text { English(points) }\end{array}$ & 91.2 & 79.3 & .000 \\
\hline Average scores of English Writing(points) & 87.4 & 77.5 & .000 \\
\hline $\begin{array}{l}\text { Average number of words in extracurricular } \\
\text { English reading(ten thousand words/student) }\end{array}$ & 21.5 & 0 & .000 \\
\hline $\begin{array}{l}\text { Average number of Wechat English short } \\
\text { articles and posts(number/student) }\end{array}$ & 23.6 & 0 & .000 \\
\hline $\begin{array}{l}\text { Average number of words per English } \\
\text { essay(word) }\end{array}$ & 186 & 0 & .000 \\
\hline
\end{tabular}

More importantly, questionnaire survey and group interviews before and after the experiment found that the proportion of "students studying actively and conscientiously", "having a clear goal and career plan" and "having a clear plan for postgraduate entrance examination" during the pretest was $36 \%, 35 \%, 30 \%$ respectively. The proportion of the control group in the post-test did not change much from the pre-test, but the experimental group became $66 \%$, $63 \%, 68 \%$ respectively, which shows an increase of about $30-38 \%$. Furthermore, the experimental group realized that their goals are closely related to the great rejuvenation of the Chinese nation through the integration of ideals and beliefs in the English major courses. More than $65 \%$ of the students have turned to active and serious learning attitudes, and the increase in English micro-reading and micro-writing is preparing for further development in the postgraduate entrance examination. In order to achieve better career aspirations, test scores will naturally be improved. See Table 3 for details. On the contrary, more than $60 \%$ of the students in the control group did not have an active and serious learning attitude, current learning goals and career plans, and the improvement of course test scores was only about $2 \%$. 
Table 3. Study attitude, ideals and beliefs and career planning before and after testing

\begin{tabular}{|l|c|c|c|}
\hline \multicolumn{1}{|c|}{ Item } & $\begin{array}{l}\text { Experimental } \\
\text { Group } \\
\text { N=108 } \\
\text { students }\end{array}$ & $\begin{array}{l}\text { Control } \\
\text { Group } \\
\text { N=111 } \\
\text { students }\end{array}$ & $\begin{array}{c}\text { Sig } \\
\text { P-value }\end{array}$ \\
\hline $\begin{array}{l}\text { Number of students study positively in } \\
\text { pre-test(student, \%) }\end{array}$ & $39,36.11 \%$ & $40,36.04 \%$ & .144 \\
\hline $\begin{array}{l}\text { Number of students study positively in } \\
\text { post-test(student, \%) }\end{array}$ & $71,65.74 \%$ & $43,38.74 \%$ & .000 \\
\hline $\begin{array}{l}\text { Number of students have clear life goals and career } \\
\text { plan in pre-test (student, \%) }\end{array}$ & $37,34.43 \%$ & $39,35.14 \%$ & .151 \\
\hline $\begin{array}{l}\text { Number of students have clear life goals and career } \\
\text { plan in post-test (student, \%) }\end{array}$ & $68,62.96 \%$ & $42,37.84 \%$ & .000 \\
\hline $\begin{array}{l}\text { Number of students planned to take entrance exam for } \\
\text { postgraduate in pre-test (student, \%) }\end{array}$ & $33,30.56 \%$ & $35,32.41 \%$ & .143 \\
\hline $\begin{array}{l}\text { Number of students planned to take entrance exam for } \\
\text { postgraduate in post-test (student, \%) }\end{array}$ & $74,68.52 \%$ & $39,35.14 \%$ & .000 \\
\hline
\end{tabular}

The group interview found that more than $80 \%$ of students in the experimental group agree with the teaching reform mode of "ideal and belief education integrates into professional courses". Although some students think that there are a lot of extracurricular reading materials, they also know that there is no harm in reading more. And these reading materials really make them rethink their ideals in life. Many people have a more positive positioning of their career plans, which is also the main reason for the increase in the number of postgraduate entrance examinations.

In addition, students in the experimental group conducted a comparison between China and other countries by reading the reports of the Chinese and foreign media on the prevention and control of the COVID-19 epidemic in various countries in the course WeChat group. Since the discovery of the COVID-19 epidemic in late January 2020, the Chinese government has acted vigorously and organized national support for Wuhan. In the fight against the epidemic, the epidemic was controlled in just over a month, and the national economy began to recover; and some Western countries that ignored the lives of the people simply passively resisted the epidemic, which caused the epidemic to spread after half a year, severe economic decline, and a surge in unemployment. These analyses and comparisons have deepened the experimental group's students' understanding and confidence in the superiority of the socialist system with Chinese characteristics. More than $95 \%$ of the students approve of the government's epidemic prevention and control policies, are willing to actively participate in epidemic prevention and control, and truly feel the Chinese government is a government that focuses on the interests of the vast majority of the people and serves the people wholeheartedly. The Chinese system, Chinese culture and Chinese plans have great advantages. The Chinese nation has a great spirit of sacrifice and dedication, and has a great sense of pride in being a Chinese. Western capitalist developed countries are not paradise on earth. 


\section{Mll Macrothink}

The survey data of the two groups of students are as follows: $99 \%$ of students in the experimental group deepen their understanding and confidence in the superiority of the socialist system with Chinese characteristics, and agree with the government's epidemic prevention and control policy, while only $70 \%$ of the control group think so; $97 \%$ of students in the experimental group were willing to actively participate in the epidemic prevention and control, while only $66 \%$ of the control group think so; $94 \%$ of the experimental group students think that the Chinese government is for the benefit of the overwhelming majority of the people, but only $67 \%$ of students in the control group agree with them; $98 \%$ of students in the experimental group think the Chinese system, Chinese culture and Chinese program have great advantages, the Chinese nation has a great spirit of sacrifice and dedication, and they have great pride to be Chinese, but only $62 \%$ of the control group have the same idea; $96 \%$ of students in the experiment group think that the western capitalist developed countries are not paradise on earth, and any system or country will have its own weaknesses, while only $61 \%$ of the control group show their agreement. Detailed survey data are shown in Table 4.

Table 4. Comparison of Chinese and foreign systems and national cultures from the perspective of prevention and control of the COVID-19 epidemic

\begin{tabular}{|c|c|c|c|}
\hline Item & $\begin{array}{l}\text { Experimental } \\
\text { Group } \\
\mathrm{N}=108 \\
\text { students }\end{array}$ & $\begin{array}{l}\text { Control } \\
\text { Group } \\
\mathrm{N}=111 \\
\text { students }\end{array}$ & $\begin{array}{c}\text { Sig } \\
\text { p-value }\end{array}$ \\
\hline $\begin{array}{l}\text { The number of student supporting the Chinese } \\
\text { government to adopt strict prevention and control } \\
\text { policies(student, \%) }\end{array}$ & $107,99.07 \%$ & $78,70.27 \%$ & .000 \\
\hline $\begin{array}{l}\text { Number of people willing to actively participate in } \\
\text { epidemic prevention and control(student, \%) }\end{array}$ & $105,97.22 \%$ & $73,65.77 \%$ & .000 \\
\hline $\begin{array}{l}\text { The number of student who think the Chinese } \\
\text { government is a good government for } \\
\text { people(student, \%) }\end{array}$ & $102,94.44 \%$ & $75,67.57 \%$ & .000 \\
\hline $\begin{array}{l}\text { The number of student think that the Chinese system } \\
\text { and Chinese culture have great } \\
\text { advantages(student, \%) }\end{array}$ & $106, \quad 98.15 \%$ & $69,62.16 \%$ & .000 \\
\hline $\begin{array}{l}\text { The number of student who think that capitalist } \\
\text { developed countries are not in heaven(student, \%) }\end{array}$ & $104, \quad 96.30 \%$ & $61,54.95 \%$ & .000 \\
\hline
\end{tabular}

\section{Conclusion and Discussion}

(1)After integrating ideal and belief education into the English major courses during the teaching reform experiment of 32 teaching weeks in 1 academic year, it is found that more than $65 \%$ of students in the experimental group have turned their learning attitudes to be active and serious, and they are preparing for postgraduate entrance examinations to further develop their studies to achieve better career ideals. The total amount of English micro-reading and micro-writing has increased by 361 and 6.5 thousand words respectively, and the examination scores of professional courses have increased by $13-15 \%$. 
On the contrary, more than $60 \%$ of the students in the control group who maintained the original conventional teaching mode did not have a positive and serious learning attitude, positive learning goals and career plans, and the improvement of the course examination scores was only about $2 \%$.

This situation shows that college students' ideal and belief education is conducive to the positive change of learning attitude and the improvement of academic performance, which has a positive effect on their career after graduation.

(2)Through the online multilingual reading and analysis comparison, more than $95 \%$ of the students in the experimental group agreed with the government's epidemic prevention and control policies and were willing to actively participate in the epidemic prevention and control. They truly felt that the Chinese government is a government that focuses on the interests of the vast majority of the people and serves the people wholeheartedly. The Chinese system and culture and the China's solutions have great advantages. The Chinese nation has a great spirit of sacrifice and dedication. It has a great sense of pride to be a Chinese, and western capitalist developed countries are not a paradise on earth. Around $40 \%$ of students in the control group, who did not read the materials and carry out comparison, have vague understanding of the above issues.

This situation shows that college students should pay attention to the development of the community with a shared future and different reports of various countries in the world, analyze the global news, and through analysis and judgment, they can distinguish right from wrong, understand the truth, choose and adhere to the correct ideals, beliefs and professions, and promote the common development of human society.

(3)More than $80 \%$ of the students in the experimental group recognized the teaching reform mode of "integrating ideal and belief education into professional courses". This mode has a significant role in promoting the ideals and beliefs of Chinese college students and the learning of professional courses. High political and ideological awareness and objective and fair analysis of social issues, choose appropriate materials and methods of integration. This study provides case experience and reference for the ideal education mode of universities in various countries.

\section{References}

Chen, Y. (2017). Striving to improve the scientific level of Ideological and political education for college students. Education Modernization, 17(47), 49-56.

Cheng, Y. \& Zhang, L. (2011). Development of College Students' English learning attitude questionnaire and its reliability and validity. Journal of Tianjin Foreign Studies University, $10(3), 41-48$.

Guo, H., Yan, G. (2019). Investigation on the current situation of College Students' autonomous learning and analysis of influencing factors -- Taking Z University as an example. Journal of Taiyuan City Vocational and Technical College, 9(11), 101-104 
Li, Y. (2017). Path selection of ideological and political education innovation and development in application-oriented universities. Social Science Front, 8(5), 273-276.

Liu, J. (2020). On the scientific connotation of Xi Jinping's struggle for happiness and its educational value to the development of college students. Higher Education Journal, 16(24), $18-21$.

Liu, R. (2018). Research on the Ideal and Belief Education of Young University Teachers (Doctoral dissertation). Nanchang: Jiangxi University of Technology.

Liu, T. (2017). Reflections on the proportion of Chinese elements in current college English textbooks. Cultural and Educational Materials, 22(26), 211-212.

Liu, Z. (2018). Research on the Status Quo and Countermeasures of Ideals and Beliefs Education of College Student Party Members in Shaanxi. Yan'an: Yan'an University.

Lv, S., Chen, X., \& Pan, X. (2017) Investigation on the status quo of College Students' ideals and beliefs: a case study of Jiangxi Province. Journal of Jinggangshan University (Social Science Edition), 38(06), 37-44.

Ruan, J., Zhang, J. (2020). New dimensions of Chinese Dream Education in the new era. Academic Exploration, 25(7), 134-138.

Shen, C. (2018). Research on the Status Quo and Countermeasures of College Students' Ideal and Belief Education Under the New Media Environment (doctoral dissertation). Qinghuangdao: Yanshan University.

Shi, M., \& Sun., F. (2018). Study on the learning status of contemporary college students. University Education, 21(8), 157-159.

Wang, H. (2018). Visiting the English Translation Team of The Governance of China. https://doi.org/10.4236/als.2018.61003

Wang, Q., \& Lin, J. (2018). Empirical analysis of current college students' learning status and learning motivation -- Taking College Students in Shanxi University City as an example. University Education, 11(12), 143-146

Wang, Y. (2019). Research on the Path of College Students' Ideal and Belief Education from the Perspective of Micro-era (Doctoral dissertation). Xi'an: Xi'an Petroleum University.

Yang, L., \& Yang, X. (2020). Investigation and Research on College Students' learning engagement. Contemporary Education Practice and Teaching Research, 21(03), 241-242.

Zhang, X. (2019). Discussion on the path of improving the effectiveness of College Students' Ideological and political education by teachers of professional courses. Journal of Heilongjiang University of Education, 38(8), 25-27.

Zou, X., Jiang, S., Xu, B., Ma, Z., He, J., \& Guan, Z. (2019) Investigation and analysis of College Students' negative learning. New West, 19(21), 54-55. 